\title{
Primordial Optic Nerve
}

National Cancer Institute

\section{Source}

National Cancer Institute. Primordial Optic Nerve. NCI Thesaurus. Code C34273.

The optic stalk, which is the constricted, proximal portion of the optic vesicles found in the embryo, and in which the lumen gradually obliterates as axons of ganglion cells accumulate in the inner layer and form the optic nerve. 